\title{
Efektywność publicznej i sądowej kontroli uczciwości umów kredytów hipotecznych powiązanych z kursem waluty obcej
}

\section{Wprowadzenie}

Wprowadzenie przez banki do obrotu konsumenckiego (głównie w latach 2005-2008) produktu w postaci kredytu powiązanego z kursem waluty obcej, zwłaszcza franka szwajcarskiego (CHF), wywołało szereg problemów prawnych i społecznych, było przyczyną licznych działań władz publicznych, a także stało się powodem wielu procesów sądowych.

Niniejszy artykuł ocenia efektywność władz publicznych oraz sądów powszechnych w zakresie kontroli uczciwości umów kredytów powiązanych z kursem waluty obcej. Publiczna kontrola uczciwości umów oznacza działania podejmowane przez władze publiczne, przede wszystkim przez nadzorcę rynku, ale także ustawodawcę, zmierzające do zapobieżenia, a później do generalnego uregulowania problemu. $Z$ kolei metoda indywidualnej kontroli prawnej to podejmowanie działań przed sądem powszechnym przez osoby dotknięte skutkami nieuczciwych umów kredytowych. Artykuł omawia mechanizmy kontroli publicznoprawnej, jakie zostały zastosowane wobec pojawiającego się problemu nieuczciwych umów kredytów powiązanych z kursem waluty obcej wprowadzonych do obrotu rynkowego przez banki oraz zarysowujące się stanowisko sądów powszechnych wobec tego problemu. Przedstawia również ocenę skuteczności podejmowanych działań, z uwzględnieniem generalnego celu, jakim jest wyeliminowanie nieuczciwych postanowień umownych z obrotu rynkowego. 
Ochrona konsumenta należy do wartości konstytucyjnych. Zgodnie $\mathrm{z}$ art. 76 ustawy zasadniczej ${ }^{1}$ władze publiczne mają obowiązek chronić konsumentów przed nieuczciwymi praktykami rynkowymi, a zakres tej ochrony regulują ustawy². Zgodnie z art. 6 ust. 1 Dyrektywy 93/13/ EWG w sprawie nieuczciwych warunków w umowach konsumenckich $^{3}$ państwa członkowskie Unii Europejskiej (UE) zobowiązały się, że nieuczciwe warunki w umowach zawieranych przez sprzedawców lub dostawców z konsumentami nie będą wiążące dla konsumenta, a umowa w pozostałej części będzie nadal obowiązywała strony, jeżeli jest to możliwe po wyłączeniu z niej nieuczciwych warunków. Bardziej generalnie, niedopuszczalność stosowania nieuczciwych postanowień umownych należy wywodzić z zasady państwa prawnego, ochrony konsumentów przed nieuczciwymi praktykami rynkowymi oraz zasadami współżycia społecznego. Dyrektywę 93/13/EWG i implementujące jej postanowienia przepisy art. $385^{1}$ i następnych Kodeksu cywilnego ${ }^{4}$ należy więc rozumieć jako bliższe sprecyzowanie, jakie postanowienia umowne powinny być uznawane za nieuczciwe, a także jakie są skutki umieszczania nieuczciwych postanowień umownych w umowach z konsumentami.

Celem niniejszego artykułu jest przedstawienie działań podejmowanych przez władze publiczne i ocena ich efektywności dla realizacji celu, jakim jest ochrona konsumenta przed nieuczciwymi warunkami umownymi, w tym przypadku zawartymi w umowach kredytów powiązanych z kursem waluty obcej. Artykuł koncentruje się wyłącznie na kwestii nieuczciwości klauzul związanych z powiązaniem kredytu $z$ kursem waluty obcej (klauzule indeksacyjne), pozostawiając na boku inne zagadnienia ${ }^{5}$.

${ }^{1}$ Konstytucja Rzeczypospolitej Polskiej z dnia 2 IV 1997 r. (Dz.U. Nr 78, poz. 483 ze zm.), dalej „Konstytucja RP”.

${ }^{2}$ Wyróżnia się tu: centralny organ właściwy dla ochrony konsumentów, którym jest Prezes Urzędu Ochrony Konkurencji i Konsumentów, regulatora rynku, czyli Komisję Nadzoru Finansowego, miejskich i powiatowych rzeczników praw konsumentów, organizacje społeczne, a wreszcie sądy powszechne. Zob. J. Koćwin, Ochrona i edukacja konsumenta. Instytucjonalne zapobieganie działaniom nieetycznym i nieprawidłowościom w branży usług finansowych, w: Instytucje w teorii i praktyce, pod red. B. Borkowskiej, Wrocław 2012.

${ }^{3}$ Dz.U. UE L 95 z 21 IV 1993 r., Dz.U. UE polskie wydanie specjalne, rozdz. 15, t. 2, s. 288.

${ }^{4}$ Ustawa z dnia 23 IV 1964 r. Kodeks cywilny (tekst jedn. Dz.U. 2017, poz. 459 ze zm.), dalej „k.c.".

${ }^{5}$ Obszerne omówienie zawiera monografia E. Rutkowska-Tomaszewska, Ochrona prawna klienta na rynku usług bankowych, Wolters Kluwer, Warszawa 2013. 


\section{Nieuczciwość klauzul indeksacyjnych w umowach kredytów powiązanych z kursem waluty obcej}

Szczegółowe powody, dla których klauzule indeksacyjne zawarte w umowach kredytu powiązanego z kursem waluty obcej są nieuczciwe, były już przedmiotem zainteresowania doktryny i nie będą tutaj szerzej omawiane ${ }^{6}$. Dla jasności dalszego wywodu należy jednak wskazać, że umowy kredytu powiązanego z kursem waluty obcej (tj. zarówno umowy kredytu denominowanego, jak i indeksowanego ${ }^{7}$ ) są nieuczciwe $\mathrm{z}$ dwóch generalnych powodów. Po pierwsze, kredytobiorcom nie przedstawiono w sposób jasny i przejrzysty wszystkich skutków ekonomicznych związanych z zaproponowaną umową. W szczególności kredytobiorców nie ostrzeżono, że zgodnie z umową wysokość ich zadłużenia będzie się zmieniać każdego dnia wraz ze zmianą kursu waluty i może być znacznie wyższa niż kwota

${ }^{6}$ Patrz J. Czabański, Walutowe klauzule waloryzacyjne w umowach kredytów hipotecznych. Analiza problemu, „Palestra” 2016, nr 6, s. 63; T. Czech, Kontrola abuzywności klauzuli walutowej w umowie kredytu. Glosa do wyroku SN z 19 marca 2015 r. (IV CSK 362/14), "Monitor Prawa Bankowego" 2015, nr 10, s. 20; A. Jurkowska-Zeidler, Asymetria ryzyka a zasada sprawiedliwości społecznej na tle problemu kredytów we frankach szwajcarskich, "Gdańskie Studia Prawnicze" 2016, t. 25, s. 131; K. Koźmiński, Bank Loans Denominated and Indexed to Foreign Currency: A Polish, Ukrainian or Europe-Wide Problem?, "Studia Iuridica” 2017, t. 71, s. 117; D. Krajewski, Charakter prawny typowej umowy o kredyt denominowany do waluty innej niż waluta polska, "Monitor Prawniczy” 2017, nr 21, s. 1163 (cz. I); "Monitor Prawniczy" 2017, nr 22, s. 1219 (cz. II); B. Lanckoroński, Zmiany kursu franka szwajcarskiego a sytuacja prawna kredytobiorców - wybrane zagadnienia, "Zeszyty Prawnicze Biura Analiz Sejmowych Kancelarii Sejmu" 2015, nr 1, s. 38; Życie umowy konsumenckiej po uznaniu jej postanowienia za nieuczciwe na tle orzecznictwa TSUE, pod red. M. Romanowskiego, C.H. Beck, Warszawa 2017.

${ }^{7}$ Brak jest legalnej definicji kredytu denominowanego i indeksowanego. Przez kredyt indeksowany (waloryzowany) należy rozumieć kredyt, którego kwota jest określona w walucie polskiej, lecz w momencie wypłaty kwotę tę przelicza się na równowartość w walucie obcej według kursu kupna danej waluty stosowanego przez bank. Równowartość kredytu wyrażona w walucie obcej stanowi następnie podstawę do wyliczania wysokości rat spłaty kredytu i wysokości zadłużenia kredytobiorcy. Zobowiązanie kredytobiorcy do spłaty wyznaczane jest po przeliczeniu na walutę polską według kursu sprzedaży stosowanego przez bank. Kredyt denominowany to kredyt, którego kwota w umowie jest określona w walucie obcej, lecz wypłacana może być wyłącznie w złotych, po przeliczeniu według kursu kupna waluty obcej stosowanego przez bank. Kredytobiorca jest zobowiązany do spłaty rat kredytu w walucie polskiej po przeliczeniu z waluty obcej na złote według kursu sprzedaży stosowanego przez bank w dniu spłaty (zob. J. Czabański, Walutowe klauzule waloryzacyjne..., s. 64). Ekonomicznie oba typy umów działają w ten sam sposób z punktu widzenia kredytobiorcy oraz banku. 
udzielonego kredytu, przekroczyć wartość kredytowanej nieruchomości, a nawet doprowadzić ich do bankructwa ${ }^{8}$. Po drugie, umowy przewidywały wykorzystanie dwóch różnych kursów stosowanych do przeliczeń: najpierw wypłacanej kwoty kredytu (kurs kupna), a następnie rat spłaty kredytu (kurs sprzedaży), przy czym każdy z tych kursów był wyznaczany w sposób arbitralny przez bank, a umowa nie określała ani różnicy pomiędzy tymi kursami (tzw. spread), ani ich powiązania z kursem rynkowym. Kredytobiorcy musieli zaś spłacać kredyt po przeliczeniu zgodnie z kursami wyznaczonymi przez bank i nie mieli możliwości spłaty kredytu w walucie indeksacji. Taki mechanizm powodował, że bank miał swobodę w określaniu wysokości zobowiązań kredytobiorców poprzez wyznaczanie kursów stosowanych do przeliczeń 9 .

\section{Wprowadzanie kredytów powiązanych z kursem waluty obcej na rynek i publicznoprawna próba ich kontroli}

Działalność bankowa poddana jest szczególnemu nadzorowi. Nadzorcą rynku jest Komisja Nadzoru Finansowego $(\mathrm{KNF})^{10}$, a w aspekcie makroostrożnościowym od roku 2015 rolę tę pełni Komitet Stabilności Finansowej ${ }^{11}$. W latach 1998-2008 rolę nadzorczą w odniesieniu do banków pełniła Komisja Nadzoru Bankowego (KNB), której jednym

${ }^{8}$ Wymóg przejrzystości umowy i prawo konsumenta do uzyskania pełnej informacji o warunkach umowy jest zasadniczym prawem konsumenta, podkreślanym w orzecznictwie Trybunału Sprawiedliwości Unii Europejskiej (zob. zwłaszcza wyrok z 20 IX 2017 r. Ruxandra Paula Andriciuc i in. przeciwko Banca Românească SA (sygn. C-186/16, niepublikowany) oraz Sądu Najwyższego (SN) (zob. wyrok SN z 20 VI 2006 r., sygn. SK 7/06, OSNP 2007, nr 13-14, poz. 207). Zob. też E. Rutkowska-Tomaszewska, op. cit., s. 326-331.

${ }^{9}$ Zgodnie z art. $385^{3}$ pkt 20 k.c. "[w] razie wątpliwości uważa się, że niedozwolonymi postanowieniami umownymi są te, które w szczególności [...] przewidują uprawnienie kontrahenta konsumenta do określenia lub podwyższenia ceny lub wynagrodzenia po zawarciu umowy bez przyznania konsumentowi prawa odstąpienia od umowy".

${ }^{10}$ Ustawa z dnia 21 VII 2006 r. o nadzorze nad rynkiem finansowym (tekst jedn. Dz.U. 2017, poz. 196).

${ }^{11}$ Ustawa z dnia 5 VIII 2015 r. o nadzorze makroostrożnościowym nad systemem finansowym i zarządzaniu kryzysowym w systemie finansowym (tekst jedn. Dz.U. 2017, poz. 1934). W skład Komitetu wchodzi Minister Finansów, Prezes Narodowego Banku Polskiego, Przewodniczący Komisji Nadzoru Finansowego oraz Prezes Zarządu Bankowego Funduszu Gwarancyjnego (art. 7 ustawy). 
z członków był Generalny Inspektor Nadzoru Bankowego (GINB), wchodzący w skład Narodowego Banku Polski (NBP), który sprawował nadzór bankowy przez rokiem 1998. Zgodnie z ustawą o nadzorze nad rynkiem finansowym KNF jest organem właściwym w sprawach nadzoru nad rynkiem finansowym i ma między innymi prawo do wydawania zezwolenia na utworzenie banku, jak również miała prawo do wydawania rekomendacji dotyczących dobrych praktyk ostrożnego i stabilnego zarządzania bankami. Obecnie uprawnienie do wydawania rekomendacji ma Komitet Stabilności Finansowej.

Pierwszym działaniem władz nadzoru bankowego w zakresie kredytów powiązanych z kursem waluty obcej było ostrzeżenie wystosowane do prezesów banków w piśmie Generalnego Inspektora Nadzoru Bankowego z 3 lipca 2002 r. ${ }^{12} \mathrm{~W}$ piśmie tym GINB wskazywał m.in., że "Niezabezpieczone ryzyko kursowe dłużnika (np. przychodami w walucie obcej, depozytem walutowym, instrumentami finansowymi) może w sytuacji dużej, skokowej zmiany kursu walutowego spowodować znaczące podrożenie kosztów obsługi długu, zwłaszcza jeśli zmiana taka miałaby trwały charakter. $W$ przypadku takiego scenariusza ryzyko kursowe kredytobiorcy, krystalizujące się w postaci realnych strat z tytułu różnic kursowych, faktycznie przekształca się w ryzyko kredytowe banku. A zatem ryzyko kursowe wpisane w sprzedany przez bank produkt kredytowy i de facto przerzucone na kredytobiorcę może «powrócić» do banku w postaci ryzyka kredytowego". W rezultacie GINB zalecał wprowadzenie analizy wpływu ryzyka kursowego na zdolność do obsługi zadłużenia przez kredytobiorcę, a także „upewnienia się, że klienci rozumieją charakter ryzyka, jaki ponoszą w związku z zawieranymi transakcjami". Powyższe ostrzeżenie nie odniosło skutku i coraz więcej kredytów było udzielanych w formie kredytu powiązanego z kursem waluty obcej, co przedstawia rysunek 1 .

Jak wyraźnie widać, kredyty powiązane z kursem waluty obcej były udzielane przed rokiem 2005 na niewielką skalę (zwłaszcza jeżeli chodzi o ich ogólną wartość), aby w latach 2005-2008 szybko rosnać, a w efekcie stanowić dominującą formę kredytu hipotecznego w tamtym okresie. Dopiero począwszy od 2009 r., a zwłaszcza po roku 2011 ta forma kredytów praktycznie zniknęła z rynku.

12 Pismo Generalnego Inspektora Nadzoru Bankowego z 3 VII 2002 r. nr NB/BI/ PB/022-1/19/02, opublikowane w „Prawo Bankowe” 2002, nr 9(61), s. 79. Nieco wcześniej, w 2000 r., KNB wprowadziła wymogi kapitałowe dla otwartych pozycji walutowych dla banków. 


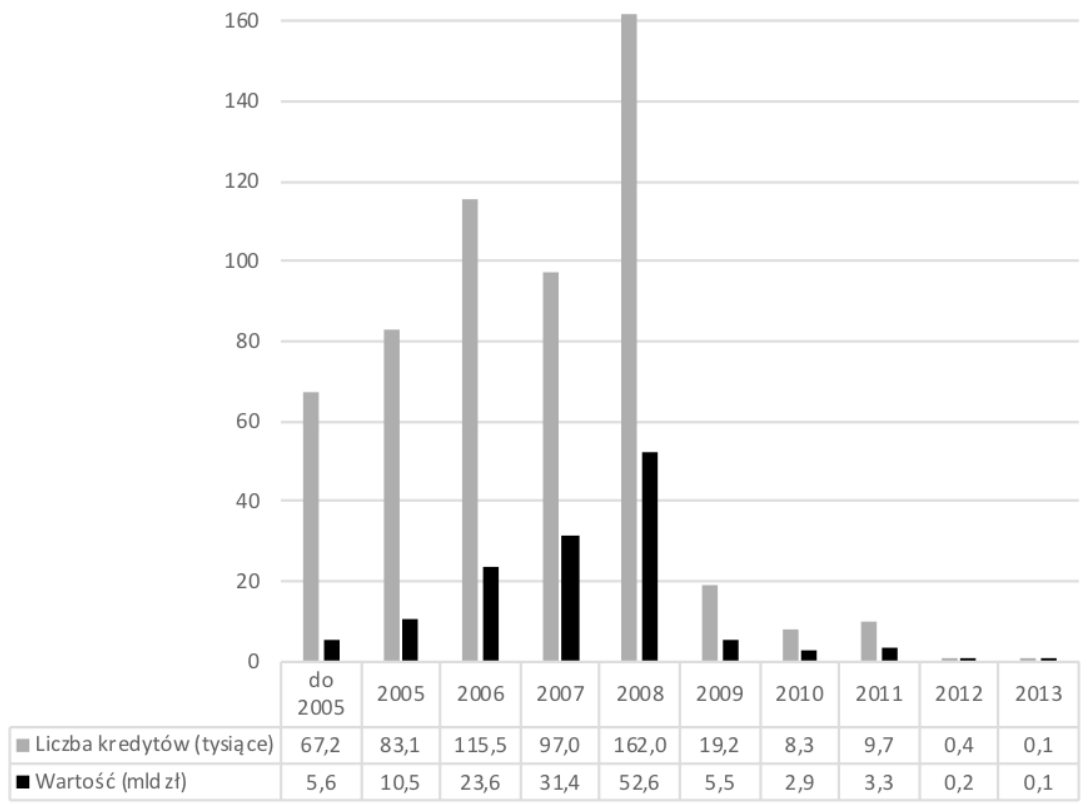

Rysunek 1. Liczba i wartość kredytów powiązanych z kursem waluty obcej udzielanych w poszczególnych latach

Źródło: Wptyw silnego osłabienia PLN względem CHF na stabilność polskiego sektora bankowego oraz sytuację finansową kredytobiorców, Prezentacja Przewodniczącego KNF wygłoszona na posiedzeniu Komisji Finansów Publicznych Sejmu RP 3 lutego 2015 r., https:/ / www.knf.gov.pl/poprzednie_lata/raporty_opracowania/ bankowy?articleId=60583\&p_id=18 (dostęp: 18 III 2018).

Podkreślaną zaletą kredytów powiązanych z kursem waluty obcej było niższe oprocentowanie. W latach 2006-2008 referencyjna stopa oprocentowania dla CHF wynosiła 1-3\% i była o około 3 punkty procentowe niższa niż analogiczna stopa dla PLN.

Różnica w wysokości oprocentowania kredytu przekładała się na znaczące różnice w wysokości raty spłaty kredytu. Dla przykładowego kredytu na 300 tys. PLN udzielonego na okres trzydziestu lat miesięczna rata spłaty wynosi 1798,65 PLN przy oprocentowaniu 6\%, a 1265,81 PLN dla oprocentowania 3\%. Im wyższa kwota kredytu, tym większe są w liczbach bezwzględnych różnice w wysokości raty spłaty kredytu, a więc różnice w oprocentowaniu stają się bardziej istotne dla kredytobiorcy. Najwyższe kwoty dotyczą oczywiście kredytów hipotecznych i to wyjaśnia, dlaczego akurat w tym obszarze kredyty powiązane z kursem waluty obcej stały się tak popularne. 


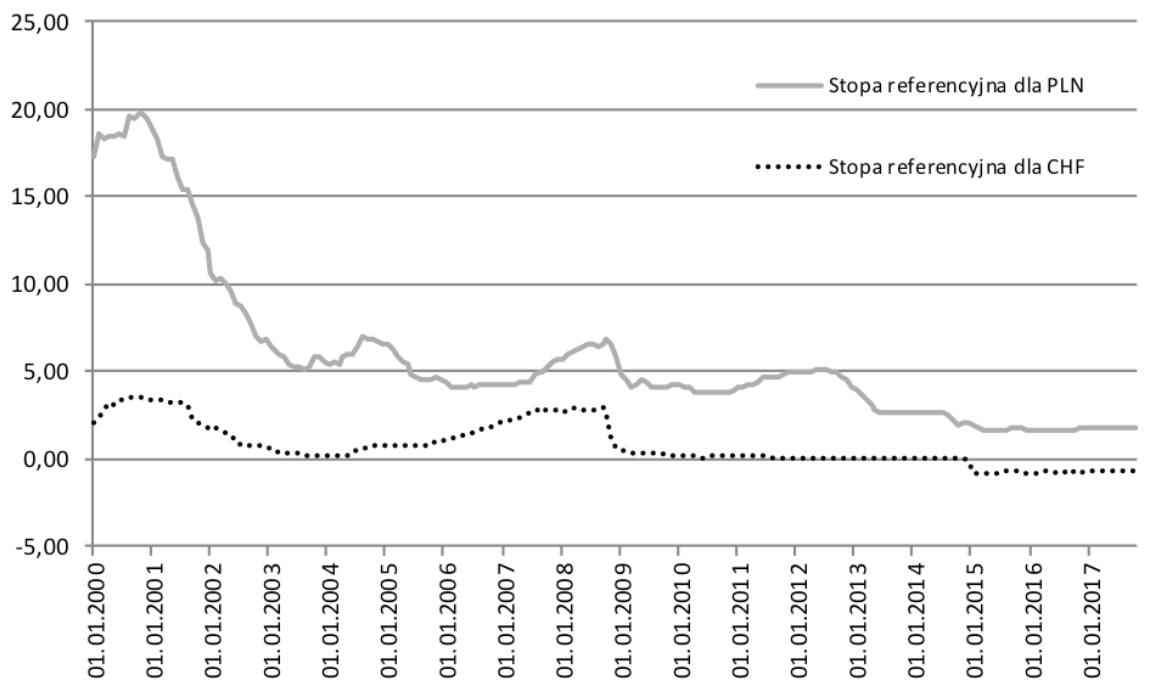

Rysunek 2. Porównanie stopy procentowej dla CHF i PLN

Źródło: 3-Month or 90-day Rates and Yields: Interbank Rates dla Szwajcarii i Polski, Economic Data, Federal Reserve Bank of Saint Louis, fred.stlouisfed.org (dostęp: 25 II 2018).

Jednocześnie należy zauważyć, że ryzyko kursowe dla kredytobiorcy jest tym wyższe, im wyższa jest kwota kredytu (większy jest bowiem wpływ zmian kursu waluty w stosunku do majątku kredytobiorcy), a także im dłuższy jest okres spłaty kredytu, kiedy to ryzyko może się zmaterializować. I znów, oba te warunki są spełnione właśnie dla kredytów hipotecznych. Innymi słowy, kredyty hipoteczne powiązane z kursem waluty obcej są najbardziej ryzykownym produktem dla kredytobiorców spośród wszystkich kredytów, a jednocześnie przedstawiane różnice w oprocentowaniu właśnie w przypadku tych kredytów mogły stanowić istotną zaletę $\mathrm{w}$ reklamowaniu produktu.

W 2005 r. Generalny Inspektor Nadzoru Bankowego Wojciech Kwaśniak ponownie zwrócił uwagę na zwiększające się ryzyko związane z rosnącym udziałem kredytów powiązanych z kursem waluty obcej w portfelach banków i wskazał na możliwość wprowadzenia przez Komisję Nadzoru Bankowego ograniczenia lub uniemożliwienia udzielania takich kredytów ${ }^{13}$. W odpowiedzi Związek Banków Polskich (ZBP)

${ }^{13}$ Stanowisko GINB ze spotkań w dniach 18 października i 4 listopada 2005 r. cytowane w piśmie K. Pietraszkiewicza, prezesa Związku Banków Polskich, do prezesów banków z dnia 21 listopada 2005 r. opublikowane w: Biała księga kredytów frankowych, Związek Banków Polskich, marzec 2015, s. 12. Zob. także: Komisja Nadzoru Finansowego, 
powołał zespół roboczy i w listopadzie 2005 r. rozesłał do swoich członków pismo ze wskazaniem czterech możliwych wariantów postępowania $w$ odniesieniu do kredytów powiązanych $z$ kursem waluty obcej. Proponowanymi opcjami było: (1) wprowadzenie jednolitego standardu informacyjnego przy udzielaniu kredytów walutowych; (2) wprowadzenie ujednoliconych, zaostrzonych parametrów produktowych; (3) wprowadzenie limitów na finansowanie $w$ walutach wymienialnych; (4) zakaz udzielania kredytów w walutach wymienialnych.

W odpowiedzi część banków wypowiedziała się za wprowadzeniem zakazu udzielania kredytów powiązanych z kursem waluty obcej; były to: Bank BPH, Bank PEKAO, PKO Bank Polski, Bank Zachodni WBK, BRE Bank (obecnie mBank). Inne banki były przeciwne ogólnemu zakazowi, a co najwyżej postulowały wprowadzenie pewnych ograniczeń. Takie stanowisko wyrazily: Santander Consumer Bank, Bank Gospodarki Żywnościowej, Bank Polskiej Spółdzielczości, Bank Millennium, Bank Ochrony Środowiska ${ }^{14}$.

Podsumowując stanowisko banków, prezes ZBP w liście z dnia 5 grudnia 2005 r. do GINB stwierdził, że „zdecydowaną przewagę uzyskała opcja zakładająca wprowadzenie zakazu udzielania kredytów w walutach wymienialnych na cele mieszkaniowe"15. Jednak w piśmie z 8 lutego 2006 r. GINB odrzucił możliwość wprowadzenia całkowitego zakazu udzielania kredytów powiązanych z kursem waluty obcej ze względu na brak uprawnienia KNB do wprowadzenia takiego zakazu, a także ze względu na przekonanie, że zakaz taki faworyzowałby największe banki ${ }^{16}$. KNB wprowadził za to Rekomendację $\mathrm{S}^{17}$, uchwaloną w marcu 2006 r. z terminem wejścia w życie od lipca 2006 r.

Zgodnie z punktem 3.12 "[r]yzyko kursowe, wynikające $z$ gwałtownych wahań kursu złotego wobec walut obcych może doprowadzić do wzrostu ryzyka kredytowego, dlatego polityka banku w zakresie walutowych ekspozycji kredytowych zabezpieczonych hipotecznie powinna być szczególnie ostrożna”. Zgodnie z punktem 3.1.4 „[r]ekomenduje się,

Przypomnienie publicznej dyskusji o kredytach walutowych, 10 III 2015, https://www.knf. gov.pl/knf/pl/komponenty/img/knf_130218_przypomnienie_publicznej_dyskusji_ CHF_40728.pdf (dostęp: 25 II 2018).

${ }^{14}$ Ibidem, s. 12-32.

${ }^{15}$ Ibidem, s. 33.

${ }^{16}$ Ibidem, s. 35.

${ }_{17}$ Uchwała Komisji Nadzoru Bankowego z dnia 15 III 2006 r. w sprawie wydania Rekomendacji S dotyczącej dobrych praktyk w zakresie ekspozycji kredytowych zabezpieczonych hipotecznie (niepublikowana). 
aby bank w przypadku udzielania kredytów w walutach obcych analizował zdolność kredytową klienta przy założeniu, że stopa procentowa dla kredytu walutowego jest równa co najmniej stopie procentowej dla kredytu złotowego, a kapitał kredytu jest większy o $20 \% "$. Zgodnie z rekomendacją 19 "[b]ank powinien dołożyć wszelkich starań, aby przekazywane klientom informacje były zrozumiałe, jednoznaczne i czytelne". Zgodnie z punktem 5.1.5 „Rekomenduje się, aby banki w pierwszej kolejności oferowały klientom kredyty, pożyczki lub inne produkty w złotych. Bank może złożyć klientowi ofertę kredytu, pożyczki lub innego produktu w walucie obcej lub indeksowanego do waluty obcej dopiero po uzyskaniu od klienta banku pisemnego oświadczenia, potwierdzającego, że dokonał on wyboru oferty w walucie obcej lub indeksowanej do waluty obcej, mając pełną świadomość ryzyka związanego z kredytami, pożyczkami i innymi produktami zaciąganymi w walucie obcej lub indeksowanymi do waluty obcej". Zgodnie z punktem 5.1.7 "[r]ekomenduje się, aby bank przedstawiając klientowi ofertę kredytu, pożyczki lub innego produktu, w walucie obcej lub indeksowanego do waluty obcej informował klienta o kosztach obsługi ekspozycji kredytowej w wypadku niekorzystnej dla klienta zmiany kursu walutowego. Informacje takie mogą być przekazane na przykład w postaci symulacji wysokości rat kredytu. Informacje przekazywane klientowi powinny w szczególności zawierać:

a. Koszty obsługi ekspozycji kredytowej przy aktualnym poziomie kursu złotego do waluty ekspozycji kredytowej, bez zmian poziomu stóp procentowych.

b. Koszty obsługi ekspozycji kredytowej, przy założeniu, że stopa procentowa dla waluty ekspozycji kredytowej jest równa stopie procentowej dla złotego, a kapitał ekspozycji kredytowej jest większy o 20\%.

c. Koszty obsługi ekspozycji kredytowej przy deprecjacji kursu złotego do waluty ekspozycji kredytowej w skali odpowiadającej różnicy między maksymalnym i minimalnym kursem złotego do waluty ekspozycji kredytowej w ciągu ostatnich 12 miesięcy, bez zmian poziomu stóp procentowych".

Powyższe postanowienia Rekomendacji S nie były zbyt wymagające, jednak w praktyce nawet tak określone obowiązki informacyjne były pomijane. W szczególności banki przedstawiały niższe oprocentowanie kredytu indeksowanego jako jego podstawową zaletę, nie wskazując jednocześnie ryzyka związanego z konstrukcją kredytu powiązanego z kursem waluty obcej, w tym zwłaszcza faktu, że wysokość zadłużenia 
podlega ciągłym wahaniom wraz ze zmianami kursu waluty indeksacji. Niższe od kredytu złotowego oprocentowanie kredytu powodowało, że niższa była przewidywana rata spłaty kredytu, a kredyt stawał się dostępny dla większej liczby osób - wielu potencjalnych kredytobiorców słyszało w bankach, że mogą dostać kredyt, ale wyłącznie w formie kredytu indeksowanego do CHF, gdyż na kredyt w PLN nie mają zdolności kredytowej. Również i politycy w swoich ówczesnych wystąpieniach wypowiadali się na ogół przeciwko ograniczeniom w udzielaniu kredytów powiązanych z walutą obca, widząc w kredytach indeksowanych źródło możliwości taniego kredytowania potrzeb mieszkaniowych społeczeństwa, przy wciąż wysokich polskich stopach procentowych ${ }^{18}$.

Od razu należy zaznaczyć, że rekomendacje nadzoru bankowego nie stanowią źródła prawa powszechnie obowiązującego. Aczkolwiek dokładne określenie ich charakteru prawnego jest sporne w doktrynie prawa, to za najbardziej przekonującą koncepcję należy uznać pogląd o tym, że normy te stanowią tzw. miękkie prawo (soft law), a więc pozaprawny zbiór norm postępowania ${ }^{19}$. Złamanie takich reguł przed podmiot nadzorowany powodować będzie skutki w postaci podjęcia działań nadzorczych przez uprawniony organ nadzoru. Jeżeli zaś chodzi o skutki w relacjach z innymi podmiotami, np. klientów banków, to złamanie przez dany bank zapisu rekomendacji nie będzie skutkować nieważnością danej czynności prawnej, lecz może stanowić działanie niezgodne $z$ dobrymi obyczajami oraz zasadami współżycia społecznego ${ }^{20}$. Można bowiem wskazać, że minimalne normy uczciwego

${ }^{18}$ Zob. cytowane w Białej księdze wypowiedzi: Kazimierz Marcinkiewicz (ówczesny premier) - "Nie rozumiem polityki utrudniania dostępu do kredytów i nie zgadzam się z nią"; Zyta Gilowska (ówczesna wicepremier) - "Ograniczenia w udzielaniu hipotecznych kredytów walutowych przez banki trochę pogorszą sytuację obywateli i są projektem dyskusyjnym. Wprawdzie zdaniem niektórych lekkomyślnie trochę korzystali z kredytów denominowanych w walutach obcych, ale moim zdaniem obywatele są dorośli i mają prawo do pewnej dozy lekkomyślności w podejmowaniu decyzji" (Biała księga, s. 38-39).

${ }^{19}$ Zob. m.in.: T. Czech, Charakter prawny Komisji Nadzoru Finansowego, "Przegląd Prawa Publicznego" 2009, nr 11, s. 63; T. Nieborak, Rekomendacja Komisji Nadzoru Finansowego jako element nadzoru ostrożnościowego - synteza dyskusji, w: Nauka prawa finansowego po I dekadzie XXI wieku. Ksiegga pamiątkowa dedykowana Profesorowi Apoloniuszowi Kosteckiemu, pod red. I. Czai-Hliniak, Kraków 2012, s. 301; Z. Ofiarski, Rola soft law w regulacji rynku finansowego na przykładzie rekomendacji i wytycznych Komisji Nadzoru Finansowego, w: Prawo rynku finansowego. Doktryna, instytucje, praktyka, pod red. A. Jurkowskiej-Zeidler, M. Olszaka, Wolters Kluwer, Warszawa 2016, s. 137.

${ }^{20}$ Podobnie M. Bączyk, Prawo umów handlowych, w: System Prawa Handlowego, t. 5, pod red. S. Włodyki, C.H. Beck, Warszawa 2014, s. 1007. 
postępowania na danym rynku zostały wskazane właśnie $\mathrm{w}$ regulacji organu nadzoru. Fakt, że KNB (a później KNF) nie była uprawniona do stanowienia przepisów bezwzględnie obowiązujących, tłumaczy brak wprowadzenia ogólnego zakazu udzielania kredytów powiązanych z walutą obca. Jednak organ nadzoru mógł wprowadzić innego rodzaju ograniczenia, takie jak obowiązek dopasowania waluty kredytu do waluty dochodów lub aktywów (wprowadzone dopiero w Rekomendacji T w 2013 r.), nakaz ujawniania kosztów związanych ze stosowaniem spreadów (wprowadzone w Rekomendacji S(II) w 2008 r.), wymóg przedstawienia pełnej informacji o ryzyku klientowi (który w wystarczająco szczegółowej postaci nigdy nie został przez nadzór rynku sformułowany), czy wreszcie nakaz oferowania instrumentów zabezpieczających przed ryzykiem lub ograniczającym potencjalne straty klientów (taki nakaz również nigdy nie został sformułowany).

W roku 2006 także i inna instytucja odpowiedzialna za ochronę konsumentów, to jest Prezes Urzędu Ochrony Konkurencji i Konsumentów (UOKiK), zajmowała niezdecydowane stanowisko. Ówczesny prezes UOKiK Cezary Banasiński również wypowiedział się przeciwko zbyt daleko idącym ograniczeniom w udzielaniu kredytów, postulując przede wszystkim odpowiednie informowanie o ryzyku przez banki ${ }^{21}$.

21 "Argument ochrony konsumentów przed nadmiernym ryzykiem kursowym - podnoszony nie tylko przez sektor bankowy, lecz również przez instytucje broniące interesów słabszych uczestników rynku - jest z pewnością słuszny. Wydaje się natomiast, że wprowadzanie ograniczeń w udzielaniu kredytów walutowych jest rozwiązaniem zbyt daleko idącym. Podstawowym zagrożeniem, które dla konsumentów wiąże się z zaciągnięciem kredytu na przykład we frankach szwajcarskich, jest fakt, że zasadniczo to oni ponoszą koszty związane $z$ wahaniami kursowymi. Jako nieprofesjonaliści najczęściej nie potrafią odpowiednio wcześnie zareagować na zmiany cen walut. Właściwym instrumentem jest zatem z jednej strony edukowanie konsumentów w zakresie korzystania z ryzykownych instrumentów finansowych (tu otwiera się pole działania dla Generalnego Inspektoratu Nadzoru Bankowego i instytucji odpowiedzialnych za ochronę słabszych uczestników obrotu), z drugiej zaś - zwiększenie obowiązków informacyjnych banków. Konsumenci powinni być w sposób wyraźny informowani o zasadach przeliczania waluty obcej na złote. Najczęściej wypłata kredytu odbywa się po kursie kupna waluty, a spłata jego rat - po kursie sprzedaży. Ta różnica powoduje dodatkowy koszt, z którego konsumenci często nie zdają sobie sprawy. Warto podkreślić, że każdy bank ustala cenę sprzedaży i kupna waluty samodzielnie, a zatem koszt tak samo oprocentowanego kredytu może różnić się w zależności od banku. To bank - na podstawie już obowiązujących przepisów - powinien zapewnić konsumentowi rzetelną i pełną informację na temat zagrożeń i przysługujących im praw. Ostateczna decyzja, jaki rodzaj kredytu wybrać, zawsze powinna należeć do klienta" - komentarz C. Banasińskiego dla portalu money.pl z 4 VII 2006 r., https://www.money.pl/banki/wiadomosci/ 
W rezultacie w latach 2006-2008 większość udzielanych konsumentom kredytów na zakup nieruchomości mieszkalnej była powiązana z walutą obcą. Przykładowo, w roku 2008 aż 69\% nowo udzielonych kredytów hipotecznych było powiązanych z walutą CHF, a 30\% ze złotym (pozostałe waluty miały marginalne znaczenie). W $2010 \mathrm{r}$. tendencja się odwróciła i $74 \%$ kredytów było kredytami złotowymi, tylko $5 \%$ powiązanymi z CHF, a $20 \%$ z euro ${ }^{22}$. W części mogło to wynikać z rozpoczęcia rządowego programu "Rodzina na swoim”. Kredyty korzystające z dopłat państwowych do odsetek $w$ ramach tego programu mogły bowiem być udzielane wyłącznie w walucie polskiejej. Sam program działał początkowo na niewielką skalę: w roku 2007 udzielono 3981 kredytów, w 2008 r. udzielono 6625 kredytów, jednak już w 2009 r. udzielono 30 820 kredytów, w 2010 r. 43 057, a w 2011 r. 51288 kredytów²4. Coraz większa popularność programu mogła się przyczynić do spadku popularności kredytów powiązanych z kursem waluty obcej po 2008 r.

Oceniając skutki wprowadzenia Rekomendacji S, należy stwierdzić, że nie przyniosła ona oczekiwanych skutków, a zważywszy na dużą liczbę udzielanych kredytów powiązanych z walutą obcą w latach 2007 i 2008, należy uznać, że banki zignorowały nakaz ostrożnego podejścia do udzielania takich kredytów. Należy również uznać, że same wymogi Rekomendacji $S$ były zbyt łagodne i nie mogły spełnić swojej roli ${ }^{25}$.

Szczególnie ważna okazała się kwestia należytego poinformowania kredytobiorców o ryzyku związanym z proponowaną konstrukcją kredytu powiązanego z kursem waluty obcej. Ryzyko to dotyczy zarówno możliwości wzrostu bieżącej raty spłaty kredytu, jak i przede wszystkim

artykul/uokik;kazdy;sam;powinnien;decydowac;o;wyborze;kredytu,127,0,169343.html (dostęp: 25 II 2018).

${ }^{22}$ Dane za: Raport AMRON-SARFiN 4/2010 z 8 III 2011 r. Związek Banków Polskich, https://zbp.pl/public/repozytorium/Menu_gorne/O_ZBP/raporty/raport_amron_sarfin/Raport_AMRON_SARFiN_4.pdf(dostęp: 6 I 2018).

${ }^{23}$ Art. $\overline{6}$ ustawy z dnia 8 IX 2006 r. o finansowym wsparciu rodzin i innych osób w nabywaniu własnego mieszkania (Dz.U. Nr 183, poz. 1354 ze zm.).

${ }^{24}$ Dane za: Informacja o realizacji rządowego programu preferencyjnych kredytów mieszkaniowych "Rodzina na Swoim" oraz zamierzenia w sprawie wprowadzenia po dniu 31 grudnia 2013 r. systemów wspierania rodzin w zaspokajaniu potrzeb mieszkaniowych, Rada Ministrów, 29 III 2013, http://bip.kprm.gov.pl/download/75/27621/Informacja_o_realizacji_rzadowego_programu_preferencyjnych_kredytow_mieszkaniowy.pdf (dostęp: 25 II 2018).

${ }^{25} \mathrm{O}$ nieskuteczności działań nadzoru zob. też B. Nowosielska, Efektywność działań instytucji nadzorczych w zakresie ograniczania udzielania gospodarstwo domowym kredytów w walutach obcych w latach 2006-2010, „Zeszyty Naukowe Wyższej Szkoły Bankowości we Wrocławiu" 2012, nr 28, s. 61. 
wzrostu wysokości zadłużenia wraz ze wzrostem kursu waluty. Wzrost wysokości zadłużenia jest niczym nieograniczony, a tym samym w toku wykonywania umowy kredytu saldo zadłużenia może wzrosnąć ponad kwotę udzielonego kredytu, ponad wartość kredytowanej nieruchomości, a także przekroczyć wartość majątku kredytobiorcy. W rezultacie kredytobiorca może być pozbawiony możliwości dysponowania nieruchomością (jeżeli saldo zadłużenia przekracza wartość nieruchomości, jej sprzedaż jest niemożliwa, chyba że kredytobiorca spłaci pozostałe zadłużenie z innych środków), a także może prowadzić do bankructwa, jeżeli umowa kredytu zostanie wypowiedziana, a pozostały majątek kredytobiorcy nie wystarczy na pokrycie całości zobowiązania.

Ryzyko związane z kredytem powiązanym z kursem waluty obcej jest więc znacząco inne niż ryzyko zmiennej stopy procentowej. Przy wzroście oprocentowania kredytu rośnie bowiem bieżąca rata spłaty kredytu, jednak nie rośnie saldo zadłużenia z tytułu kredytu. Oznacza to, że w przypadku kłopotów finansowych kredytobiorcy i utraty możliwości regularnej spłaty kredytu kredytobiorca może poprzez sprzedaż nieruchomości spłacić całość zadłużenia. Tymczasem w sytuacji kredytu powiązanego z kursem waluty obcej skokowy wzrost kursu oznacza wzrost nie tylko bieżącej raty spłaty kredytu, ale i całego salda zadłużenia. Ryzyko to zmaterializowało się wobec wielu kredytobiorców, których obecne saldo zadłużenia znacznie przekracza kwotę udzielonego im kredytu, pomimo regularnych spłat kredytu przez ostatnie dziesięć lat ${ }^{26}$.

O ryzyku tym kredytobiorcy powinni byli być szczegółowo poinformowani. Jednak oświadczenia o ryzyku przygotowywane przez banki miały na ogół charakter czysto formalny i sprowadzały się do stwierdzenia, że kredytobiorca ponosi ryzyko kursowe, bez tłumaczenia, jaki wpływ będzie miał ewentualny wzrost kursu na wysokość zobowiązań kredytobiorcy ${ }^{27}$. Niektóre banki sporządzały osobny druk informacji

\footnotetext{
${ }^{26}$ Konsekwencje finansowe dla konkretnego kredytobiorcy zależą m.in. od wysokości kursu z dnia wypłaty kredytu oraz okresu kredytowania. W najgorszej sytuacji są osoby, które zaciągnęły kredyt w roku 2008, kiedy kurs CHF był poniżej 2 PLN/CHF.

${ }^{27}$ Typowe zapisy w umowach to: „W przypadku, gdy Kredyt jest indeksowany kursem waluty obcej, zmiana tego kursu będzie miała wpływ na wysokość Raty oraz saldo zadłużenia z tytułu Kredytu, przy czym saldo zadłużenia może przekroczyć wartość Nieruchomości. Ryzyko z tego tytułu ponosi Kredytobiorca”; „Kredytobiorca jest świadomy, że z kredytem waloryzowanym jest związane ryzyko kursowe, a jego konsekwencje wynikające z niekorzystnych wahań kursu złotego wobec walut obcych mogą mieć wpływ na wzrost kosztów obsługi Kredytu”; „Kredytobiorca oświadcza, iż jest świadomy ryzyka
} 
o ryzyku związanym z kredytem powiązanym z kursem waluty obcej. Druki te zawierały czasem odniesienie do możliwych wahań rat spłaty kredytu, ale nie pokazywały, jaki wpływ będzie miała zmiana kursu na saldo zadłużenia. Co więcej, druki te nie były materiałem informacyjnym przekazywanym klientom przed podjęciem decyzji o zaciągnięciu kredytu w walucie obcej, lecz były jednym $z$ wielu dokumentów przeznaczonych dla banku, których podpisanie było koniecznym warunkiem rozpatrzenia wniosku kredytowego, a więc był to dokument przeznaczony dla banku. W tym zakresie należy stwierdzić, że konsumentom nie przedstawiono w sposób jasny i rzetelny wszystkich konsekwencji ekonomicznych związanych z proponowanym kredytem. Brak przejrzystości umowy co do konsekwencji finansowych dla konsumenta stanowi zaś o jej nieuczciwości, jak konsekwentnie stwierdza Trybunał Sprawiedliwości Unii Europejskiej (TSUE) ${ }^{28}$.

Działania nadzoru bankowego w zakresie ograniczenia udzielania ryzykownych kredytów powiązanych z kursem waluty obcej okazały się więc początkowo nieskuteczne. Źródłem tej nieskuteczności działania był zarówno duży opór ze strony części banków (zwłaszcza tych mniejszych, które w regulacjach widziały przeszkodę w konkurowaniu o klienta z bankami większymi), jak i naciski polityczne, związane z chęcią utrzymania dostępu do taniego kredytu. Gwałtowny wzrost akcji kredytowej spowodował bowiem również znaczne ożywienie na rynku nieruchomości mieszkalnych, co spowodowało wzrost liczby budowanych mieszkań, a także wzrost ich cen.

Pierwsze ostrzeżenie co do dużej zmienności na rynku finansowym przyszło wraz z kryzysem finansowanym zapoczątkowanym upadkiem 15 września 2008 r. banku Lehman Brothers. Kryzys wywołany był przede wszystkim wynikiem udzielania kredytów hipotecznych osobom bez zdolności do ich spłacania przy akceptowaniu niewystarczającego zabezpieczenia (tzw. subprime mortgages). Ponieważ kredyty te stawały się następnie podstawą emitowania obligacji i były nabywane przez

kursowego, związanego ze zmianą kursu waluty indeksacyjnej w stosunku do złotego i akceptuje to ryzyko"; "zmiany kursów walut w trakcie okresu kredytowania mają wpływ na wysokość kwoty zaciągniętego kredytu oraz raty kapitałowo-odsetkowej”; „Kredytobiorca został poinformowany, że ponosi ryzyko: 1) zmiany kursów waluty polegające na wzroście wysokości zadłużenia z tytułu kredytu oraz wysokości rat kredytu, wyrażonych w walucie polskiej, przy wzroście kursu waluty kredytu; 2) stopy procentowej, polegające na wzrośnie raty spłaty kredytu przy wzroście stawki referencyjnej".

${ }^{28}$ Zob. m.in. wyrok TSUE z 20 IX 2017 r. Ruxandra Paula Andriciuc i in. przeciwko Banca Românească $S A$. 
wiele instytucji finansowych, kryzys rozprzestrzenił się na cały rynek finansowy. W rezultacie doszło do kryzysu na rynku akcji i wzrostu cen walut uważanych za bezpieczne, w tym CHF. W tym też czasie w Polsce doszło do zmian w organizacji nadzoru nad rynkiem finansowym. Od początku 2008 r. rolę tę zaczęła pełnić Komisja Nadzoru Finansowego. KNF opracowała drugą wersję rekomendacji, tj. Rekomendację S(II) ${ }^{29}$, która zaostrzyła wymogi wobec banków w zakresie udzielania kredytów powiązanych z kursem waluty obcej (rekomendacja weszła w życie $z$ dniem 1 kwietnia 2009 r.).

Rekomendacja S(II) starała się także zapobiec zauważonym w praktyce rynkowej nieprawidłowościom przez dowolne kształtowanie przez banki kursów walut obcych stosowanych do przeliczeń. Zgodnie z punktem 5.1.2 „Przed zawarciem umowy klient powinien otrzymać wszystkie informacje istotne dla oceny ryzyka i kosztów związanych z zawarciem umowy, w tym w szczególności informacje o ryzyku walutowym, ryzyku zmiennej stopy procentowej oraz wpływu spreadu walutowego na obciążenia z tytułu spłaty kredytu. Informacje te powinny być przedstawione $\mathrm{w}$ formie pisemnej (np. określonej w pkt 5.1.10 oraz 5.1.11). Przed zawarciem umowy klient powinien również otrzymać wszystkie istotne informacje dotyczące warunków umowy, w szczególności w zakresie praw i obowiązków klienta wynikających z tejże umowy. Na prośbę klienta bank powinien udostępnić mu z wyprzedzeniem projekt umowy. Bank powinien zapewnić wszelkie dodatkowe wyjaśnienia i informacje, o jakie poprosi klient".

Powyższy przepis miał więc nakazać bankom ujawnianie kosztów stosowanego spreadu dla wysokości zobowiązań kredytobiorcy. Obroną zaś przed zawyżaniem wysokości kursów miała być wprowadzona możliwość spłaty kredytu w walucie indeksacji. Zgodnie z pkt 5.2.4 "Na wniosek klienta bank powinien dokonać zmiany sposobu spłaty kredytu indeksowanego do waluty w taki sposób, aby spłata następowała w walucie indeksacyjnej. Zmiana sposobu spłaty powinna dotyczyć wszystkich rat od daty zmiany umowy. Bank nie może ograniczać w umowie kredytu możliwości pozyskania przez klienta waluty przeznaczonej na spłatę kredytu do zakresu usług oferowanych przez bank".

Przepis ten nie był jednak wystarczająco jednoznaczny i nie precyzował, czy możliwość spłaty kredytu ma być dostępna bezpłatnie, czy

${ }^{29}$ Uchwała Komisji Nadzoru Finansowego nr 391/2008 z 17 XII 2008 r. w sprawie wydania Rekomendacji S(II) dotyczącej dobrych praktyk w zakresie ekspozycji kredytowych zabezpieczonych hipotecznie (Dz.Urz. KNF 2008 Nr 8, poz. 45). 
też bank może pobrać opłatę z tego tytułu, jak też nie regulował kwestii opłat za prowadzenie konta walutowego czy możliwości wpłat gotówkowych w kasie. Ponadto nie dotyczył zasad wyznaczania równowartości kredytu w walucie obcej przy jego wypłacie, co w pierwszej kolejności wpływało na wysokość zobowiązania kredytobiorcy.

W rezultacie ten przepis Rekomendacji S(II) okazał się nieskuteczny. W 2009 r. Urząd Ochrony Konkurencji i Konsumentów przeprowadził analizę wzorców umownych stosowanych przez banki i stwierdził, że wszystkie skontrolowane wzorce umowne stosowane przez łącznie szesnaście banków naruszają interes konsumentów poprzez odesłanie do kursów waluty dowolnie wyznaczanych przez bank ${ }^{30}$. W rezultacie Prezes UOKiK wytoczył w kwietniu 2009 r. powództwo o uznanie klauzuli indeksacyjnej Banku Millennium za niedozwoloną. Powództwo zostało wytoczone tylko przeciwko jednemu z banków, gdyż Prezes UOKiK - błędnie, jak się później okazało - zakładał, że wyrok uznający tę klauzulę za niedozwoloną będzie odnosił skutek również do innych przedsiębiorców stosujących podobne postanowienia umowne ${ }^{31}$. Powództwo prezesa UOKiK zakończyło się wydaniem stosownego zakazu przez Sąd Ochrony Konkurencji i Konsumentów wyrokiem z 14 grudnia 2010 r. $^{32}$ Następnie analogiczne orzeczenia zapadały we wszystkich sprawach, w których przedmiotem oceny były klauzule indeksacyjne, tj.: 26 stycznia 2011 r. przeciwko BRE Bank S.A. (obecnie mBank) ${ }^{33}$; 27 sierpnia 2012 r. przeciwko BPH S.A. ${ }^{34}$; 25 czerwca 2014 r. przeciwko Bank DNB Nord S.A. ${ }^{35}$ Jak podkreślił sąd w pierwszym z orzeczeń: „Dobre obyczaje nakazuja, aby ponoszone przez konsumenta koszty związane z zawarciem umowy, o ile nie wynikają z czynników obiektywnych, były możliwe do przewidzenia. Wykładnia tych postanowień wskazuje na fakt naruszenia przez pozwanego zasady lojalnego kontraktowania i równorzędnego traktowania konsumenta. Brak okre-

${ }^{30}$ Zob. Raport dotyczacy spreadów, UOKiK, wrzesień 2009.

${ }^{31}$ W uchwale z 20 XI 2015 r. (sygn. III CZP 17/15, OSNC 2016, nr 4, poz. 40) Sąd Najwyższy przesądził, że wpis klauzuli do rejestru odnosi skutek wyłącznie wobec przedsiębiorcy będącego stroną postępowania.

32 Wyrok Sądu Ochrony Konkurencji i Konsumentów z 14 XII 2010 r., sygn. XVII AmC 426/09, "Monitor Prawa Bankowego" 2011, nr 7-8, s. 9.

${ }^{33}$ Wyrok Sądu Ochrony Konkurencji i Konsumentów z 26 I 2011 r., sygn. XVII AmC 1531/09, "Monitor Sądowy i Gospodarczy” 2014, nr 175, poz. 12313.

${ }^{34}$ Wyrok Sądu Ochrony Konkurencji i Konsumentów z 27 VIII 2012 r., sygn. XVII AmC 5344/11, „Monitor Sądowy i Gospodarczy” 2014, nr 135, poz. 9527.

${ }^{35}$ Wyrok Sądu Ochrony Konkurencji i Konsumentów z 25 VI 2014 r., sygn. VI ACa 1930/13, „Monitor Sądowy i Gospodarczy” 2016, nr 134, poz. 17933. 
ślenia w umowie sposobu ustalania kursów walutowych na potrzeby przeliczenia salda zadłużenia na walutę obcą oraz przeliczenia na złote kwoty wymaganej do spłat kredytu w rażący sposób narusza interes konsumenta [...] konsument uzależniony jest całkowicie od decyzji zarządu Banku, który ustali kursy walut w sposób znany wyłącznie jemu, zaś konsument nie ma żadnego wpływu na taką arbitralną decyzję, nie może jej w żaden sposób zweryfikować i może jedynie takiej decyzji się podporządkować".

Powyższa myśl była jednolicie podtrzymywana w kolejnych wyrokach. Rychło się jednak okazało, że uznanie określonego postanowienia umownego we wzorcu umownym za niedozwolone i wpis do rejestru klauzul zakazanych prowadzonego przez Prezesa UOKiK ma marginalne znaczenie. Banki bowiem zaprzestały oferowania tego typu kredytu, a uznanie danych postanowień za zakazane w postanowieniu dotyczącym wzorca umownego nie oznacza, że tożsame postanowienie zawarte $\mathrm{w}$ zawartej wcześniej umowie automatycznie traci $\operatorname{moc}^{36}$. W efekcie, pomimo powyżej przywołanych wyroków, umowy kredytowe były dalej wykonywane przez banki w ten sam sposób co wcześniej.

Warto się od razu przyjrzeć, jak w praktyce banki wyznaczały kursy walut. Rysunek 3 przedstawia marże pobierane przez kilka najbardziej aktywnych na rynku kredytów indeksowanych banków, poczynając od roku 2008. Wysokość marży definiuję tu jako odchylenie kursu sprzedaży CHF stosowanego przez dany bank (a używanego do wyliczenia zobowiązań kredytobiorców) ponad kurs średni NBP (który ustalany jest na podstawie notowań rynkowych $)^{37}$. Wyniki analizy jednoznacznie pokazują nieuczciwe działanie banków. W latach 2006-2008, kiedy banki masowo udzielały kredytów, stosowana marża wynosiła przeciętnie ok. 5 gr. Począwszy od roku 2009, kiedy banki przestały oferować już te kredyty, a klienci byli związani postanowieniami umownymi, marża wzrosła dwukrotnie, do $10 \mathrm{gr}$, a następnie trzykrotnie i więcej, do poziomu 15-20 gr.

${ }^{36}$ Kwestia ta należy do spornych w doktrynie i orzecznictwie. Dla potrzeb niniejszego artykułu wystarczy jednak zauważyć, że brak jest automatycznego skutku umieszczenia danego postanowienia $\mathrm{w}$ rejestrze dla braku skuteczności tożsamego postanowienia w już zawartych umowach wedle zakwestionowanego wzorca, a zwłaszcza dla analogicznych postanowień w umowach zawartych z innym przedsiębiorcą (o tzw. rozszerzonej prawomocności wpisu do rejestru klauzul niedozwolonych zob. uchwała SN z 20 XI 2015 r., sygn. III CZP 17/15, OSNC 2016, nr 4, poz. 40).

${ }^{37}$ Analogiczną metodę przyjął UOKiK w swoim Raporcie na temat spreadów. 


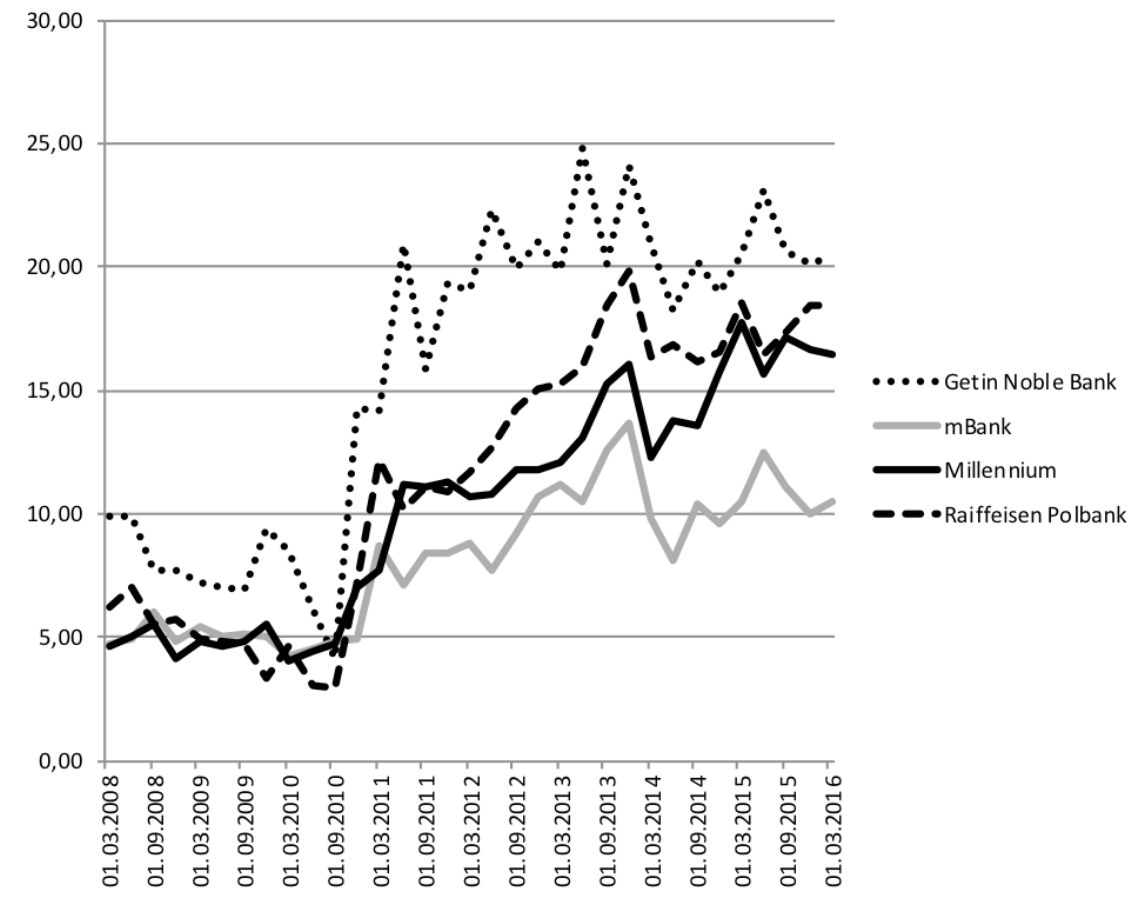

Rysunek 3. Kształtowanie się kursów sprzedaży CHF w wybranych bankach na tle kursu średniego NBP

Źródło: Opracowanie własne na podstawie danych o kursach waluty ze strony NBP oraz wskazanych banków, opublikowanych w: J. Czabański, Kredyty we frankach: jak banki naciagnę̨ty kredytobiorców na 15 mld zt, „Dziennik Gazeta Prawna” 4 V 2016.

Warto w tym miejscu dodać, że marża w kantorach tradycyjnych wynosi ok. 3 gr, a w kantorach internetowych (dynamicznie rozwijających się od 2009 r.) ok. 1 gr. Jeszcze zaś niższa jest marża na międzybankowym rynku wymiany walut i wynosi ok. 0,1 gr.

Powyższa praktyka banków i nieskuteczność Rekomendacji S(II) stały się przyczyną interwencji ustawodawcy i uchwalenia tzw. ustawy antyspreadowej $^{38}$. Ustawa ta po raz pierwszy wprowadziła do języka prawnego pojęcie kredytu denominowanego i indeksowanego do waluty obcej, jednakże bez definiowania tych pojęć. Dodatkowo ustawa nakazała, aby w przypadku kredytu denominowanego lub indeksowanego nowo zawierana umowa szczegółowo ustalała zasady określania kursu

\footnotetext{
${ }^{38}$ Ustawa z dnia 29 VII 2011 r. o zmianie ustawy - Prawo bankowe oraz niektórych innych ustaw (Dz.U. Nr 165, poz. 984).
} 
stosowanego do przeliczeń. Wreszcie, ustawa wprowadziła możliwość spłaty już udzielonych kredytów bezpośrednio w walucie indeksacji. Banki były oczywiście przeciwne wprowadzeniu tej regulacji, podnosząc, że ogranicza ona swobodę działalności gospodarczej, swobodę zawierania umów oraz obniża rentowność już zawartych umów ${ }^{39}$. Ustawa antyspreadowa, aczkolwiek wprowadziła mechanizm ucieczki kredytobiorców od zawyżanych kursów stosowanych przez banki na przyszłość, jednak nie usunęła skutków z przeszłości. Nie usunęła bowiem skutków nieuczciwych przeliczeń dokonanych przy wypłacie kredytu, jak również skutków zawyżonych kursów stosowanych do wyliczenia rat spłaty kredytu do czasu wejścia w życie ustawy antyspreadowej. Wreszcie ustawa antyspreadowa nie zawierała żadnych postanowień dotyczących kursu przeliczenia wierzytelności w przypadku wypowiedzenia umowy kredytowej. Co jeszcze ważniejsze, nie usunęła ryzyka kursowego leżącego po stronie kredytobiorców. W efekcie ustawę antyspreadową należy raczej postrzegać w kategoriach zmarnowanej szansy niż rzeczywistego rozwiązania problemu ${ }^{40}$. Z perspektywy czasu widać, że gdyby ustawodawca już w 2011 r. podjął bardziej zdecydowane działania, jak np. pozbawienie na wniosek kredytobiorcy powiązania kredytu z kursem waluty obcej, z ewentualnym rozliczeniem kredytu, jakby od początku był kredytem w złotych z właściwym dla złotego oprocentowaniem, to znacznie ograniczyłby skalę problemu, z jakim mamy do czynienia dzisiaj. Działanie ustawodawcy było jednak minimalne i nakierowane wyłącznie na zmniejszenie najbardziej widocznego nieuczciwego działania banków, jakim było zawyżanie kursu stosowanego do przeliczeń należnych rat spłaty kredytu.

Wreszcie w 2013 r. KNF wydała Rekomendację T ${ }^{41}$, która w pkt 19.1 nakazywała: „Rekomenduje się, aby bank w pierwszej kolejności oferował klientowi kredyty, pożyczki lub inne produkty w złotych lub w walucie, w jakiej uzyskuje dochód. Bank nie powinien rekomendować lub promować oferty kredytu, pożyczki lub innego produktu

\footnotetext{
${ }^{39}$ Opinia ZBP z 14 VII 2011 r. do poselskiego projektu zmiany ustawy Prawo bankowe (druk sejmowy 4413/VI kadencja), http://orka.sejm.gov.pl/Druki6ka.nsf/WWW-wszystkie/4413 (dostęp: 6 I 2018).

${ }^{40} \mathrm{O}$ wadach ustawy antyspreadowej zob. K. Zagrobelny, Kilka uwag na temat tzw. ustawy antyspreadowej, seria Aktualne Zagadnienia Prawa Prywatnego, Prawnicza i Ekonomiczna Biblioteka Cyfrowa, Wrocław 2012, s. 215-232.

${ }^{41}$ Uchwała nr 59/2013 KNF z dnia 26 II 2013 r. w sprawie wydania Rekomendacji T dotyczącej dobrych praktyk w zakresie zarządzania ryzykiem detalicznych ekspozycji kredytowych (Dz.Urz. KNF 2013, poz. 11).
} 
w walucie obcej lub indeksowanego do waluty obcej, z wyjątkiem sytuacji, w której klient uzyskuje dochód w walucie, w jakiej oferowany jest kredyt". Dopiero ta rekomendacja położyła w praktyce kres udzielania kredytów w walucie, w której kredytobiorca nie ma dochodów. Identyczny zakaz zawarty został później w Dyrektywie 2014/17/UE $\mathrm{z}$ dnia 4 lutego 2014 r. $^{42}$ w sprawie konsumenckich umów o kredyt związanych $\mathrm{z}$ nieruchomościami mieszkalnymi, a następnie $\mathrm{w}$ transponującej wymogi dyrektywy ustawie o kredycie hipotecznym z dnia 23 marca 2017 r. $^{43}$

Bardziej zdecydowane działanie podjął ustawodawca w 2015 r., kiedy tuż przed końcem kadencji sejm uchwalił 5 sierpnia ustawę o szczególnych zasadach restrukturyzacji walutowych kredytów mieszkaniowych w związku ze zmianą kursu walut obcych do waluty polskiej ${ }^{44}$. Przyjętych przez Senat RP poprawek do tej ustawy Sejm nie zdołał już rozpatrzeć ze względu na upływ kadencji.

Po zaprzysiężeniu przez Sejm RP nowo wybranego Prezydenta Rzeczypospolitej Polskiej Kancelaria Prezydenta przygotowała kilka projektów ustaw. Każdy z nich budził bardzo duże opory sektora bankowego, a jednocześnie nie spełniał oczekiwania środowiska kredytobiorców. Ostateczny projekt Prezydenta, jaki został 2 sierpnia 2016 r. skierowany do Sejmu ${ }^{45}$, zakłada już tylko częściowy zwrot spreadów i nie rozwiązuje problemu ryzyka walutowego. Projekt ten do dnia dzisiejszego pozostaje w komisji sejmowej i niewiele wskazuje na to, że zostanie uchwalony.

Opisane powyżej działania polityczne pokazują bezradność polityków wobec największego problemu na rynku finansowym, jaki miał miejsce w okresie całej III RP. Jest to problem o ogromnej skali, gdyż

${ }^{42}$ Dyrektywa Parlamentu Europejskiego i Rady 2014/17/UE z dnia 4 II 2014 r. w sprawie konsumenckich umów o kredyt związanych z nieruchomościami mieszkalnymi i zmieniająca dyrektywy 2008/48/WE i 2013/36/UE oraz rozporządzenie (UE) nr 1093/2010, Dz.Urz. UE L 60/14 z 28 II 2014 r.

${ }^{43}$ Ustawa z dnia 23 III 2017 r. o kredycie hipotecznym oraz o nadzorze nad pośrednikami kredytu hipotecznego i agentami (Dz.U. poz. 819).

${ }^{44}$ Ustawa z dnia 5 VIII 2015 r. o szczególnych zasadach restrukturyzacji walutowych kredytów mieszkaniowych w związku ze zmianą kursu walut obcych do waluty polskiej, druk sejmowy nr 3660/VII kadencja; przebieg procesu legislacyjnego http://www.sejm. gov.pl/Sejm7.nsf/PrzebiegProc.xsp?nr=3660 (dostęp: 25 II 2018).

${ }^{45}$ Skierowany przez Prezydenta RP projekt ustawy o zasadach zwrotu niektórych należności wynikających z umów kredytu i pożyczki, druk sejmowy nr 811/VIII kadencja. Przebieg procesu legislacyjnego dostępny na: http://www.sejm.gov.pl/Sejm8.nsf/ PrzebiegProc.xsp?nr=811 (dostęp: 25 II 2018). 
dotyczy około 900 tys. osób ${ }^{46}$, których zadłużenie w wielu przypadkach wzrosło, czasem niemal dwukrotnie, ponad kwotę udzielonego im kredytu. Chociaż brakuje dokładnych danych dotyczących charakterystyki udzielanych kredytów, to na podstawie cytowanego już wcześniej zestawienia KNF można stwierdzić, że w latach 2005-2008 Polacy zaciągnęli kredyty o wartości ok. 118 mld zł. Aktualne zadłużenie kredytobiorców "frankowych" wynosi zaś ok. 120 mld zł (równowartość 30 mld CHF) ${ }^{47}$, co stanowi kwotę zbliżoną do kwoty wypłaconych kredytów. Innymi słowy, przeciętnie rzecz ujmując, kredytobiorcy praktycznie nie zmniejszyli salda swojego zadłużenia pomimo 10-13 lat spłaty kredytów. Rozpatrując zaś problem w kategoriach ryzyka kursowego, można powiedzieć, że wzrost rynkowego kursu CHF/PLN o 1 zł oznaczać będzie wzrost zadłużenia kredytobiorców o 30 mld zł.

Innym aspektem nieuczciwości umów kredytowych było stosowanie zawyżonych kursów do przeliczeń. Z tego tytułu można szacować dodatkowe dochody banków kosztem kredytobiorców w ciągu ostatnich 10-13 lat na kwotę ok. 15 mld $\mathrm{z}^{48}$.

Wydaje się, że to właśnie skala problemu spowodowała niemożność interwencji politycznej. Tak jak w Stanach Zjednoczonych ukuto powiedzenie, że dana instytucja finansowa jest zbyt duża, by pozwolić jej upaść, i w związku z tym trzeba ją ratować z pieniędzy podatnika, tak w Polsce okazało się, że ze względu na powszechność udzielania kredytów powiązanych z kursem waluty obcej przez niemal wszystkie banki koalicja przeciwników regulacji jest zbyt silna. Co interesujące, jak wskazano wcześniej, nadzór bankowy w postaci Generalnego Inspektora Nadzoru Bankowego oraz Komisji Nadzoru Bankowego mógł podjąć odpowiednie działania i ograniczyć udzielanie kredytów powiązanych z kursem waluty obcej do osób posiadających dochody lub aktywa w tej walucie, albo choćby wprowadzić odpowiednie wymogi informacyjne. Na taką interwencję było dużo czasu pomiędzy 2002 a 2005 r., kiedy

\footnotetext{
46899 tys. Polaków spłaca 529 tys. kredytów powiązanych z kursem CHF - dane Biura Informacji Kredytowej na 30 VI 2016 r. podane za serwisem money.pl, https:// www.money.pl/gospodarka/wiadomosci/artykul/zadluzenie-frankowicze-nieruchomosci-kredyt,220,0,2161884.html (dostęp: 8 III 2018).

${ }^{47}$ Ogólna wartość kredytów powiązanych z kursem waluty obcej na koniec września 2017 r. wynosiła 145,1 mld zł, co stanowiło 36,4\% całego portfela kredytów. Dane za: Informacja o sytuacji banków w okresie I-IX 2017 r., Urząd Komisji Nadzoru Finansowego, grudzień 2017, https://www.knf.gov.pl/knf/pl/komponenty/img/RAPORT_O_SYTUACJI_BANKOW_2017_09_60663.pdf(dostęp: 18 I 2018).

${ }^{48}$ J. Czabański, Kredyty we frankach...
} 
istniała już świadomość zagrożenia zarówno po stronie nadzoru bankowego, jak i samych banków, ale jednocześnie kredytów tych nie udzielono zbyt wiele. Ostatecznie podjęta interwencja w 2006 r. była zarówno spóźniona, jak i niewystarczająca. Co ciekawe, praktyczny kres udzielania takich kredytów przyniosła dopiero ustawa antyspreadowa w 2011 r., choć nie zakazywała ona ich udzielania, lecz przeciwnie wprowadzała do prawa bankowego pojęcia kredytu denominowanego oraz indeksowanego. Powstaje więc ciekawe pytanie, dlaczego banki przestały udzielać takich kredytów po roku 2011. Pewną odpowiedzią może być rosnąca świadomość konsumentów dotycząca ryzykownego charakteru takich umów, na co mógł mieć wpływ kryzys finansowy rozwijający się od końca 2008 r. Inną możliwością było ograniczenie możliwości pobierania spreadu, co mogło spowodować, że kredyty te przestały już być dla banków opłacalne. Na pewno odpowiedzią nie jest różnica w oprocentowaniu pomiędzy PLN a CHF, gdyż ta utrzymywała się na podobnym poziomie.

Ustawa o kredycie hipotecznym z 23 marca 2017 r. w praktyce wykluczyła możliwość udzielania kredytów powiązanych z walutą obca, wdrażając w tym zakresie wymogi Dyrektywy 2014/17/UE z dnia 4 lutego 2014 r. w sprawie konsumenckich umów o kredyt związanych z nieruchomościami mieszkalnymi. Zgodnie z ustawą kredyt hipoteczny może zostać udzielony wyłącznie w walucie lub być indeksowany do waluty, w której konsument uzyskuje większość swoich dochodów lub posiada większość środków finansowych lub innych aktywów (art. 6 ust. 1). Nieco wcześniej, bo w 2013 r., analogiczny zakaz wprowadziła Rekomendacja T KNF.

Nie sposób wreszcie nie zauważyć, że Polska nie była pierwszym krajem, w którym tego typu kredyt wywołał bardzo niekorzystne skutki dla kredytobiorców. Specjaliści od bankowości powinni znać przypadek Australii z początku lat osiemdziesiątych ubiegłego wieku, Meksyku z połowy lat dziewięćdziesiątych czy Austrii z pierwszej dekady XXI w. Obecnie uważa się, że kredyty powiązane z kursem waluty obcej stanowią największe zagrożenie dla stabilności systemu bankowego w Europie Środkowej i Wschodniej ${ }^{49}$. Tym większe zaniepokojenie musi wzbudzać fakt, że instytucje nadzorcze zawiodły i pozwoliły na wprowadzenie tego typu produktu na masowy rynek konsumencki,

${ }^{49}$ P.J. Szpunar, A. Głogowski, Lending in Foreign Currencies as a Systemic Risk, „Macro-prudential Commentaries" 2012, no. 4. 
a następnie nie zdobyły się na podjęcie skutecznych działań w celu systemowego uregulowania tej kwestii. Wobec niemożności polityków kredytobiorcy zmuszeni zostali do skorzystania z indywidualnej drogi ochrony swoich interesów w drodze procesu cywilnego.

\section{Prywatnoprawna kontrola w drodze pozwów indywidualnych i grupowych}

W związku z brakiem rozwiązania politycznego coraz większa liczba kredytobiorców wkracza na drogę sądową. Wobec niektórych kredytobiorców to banki zgłosiły roszczenia w związku z wypowiedzeniem umowy kredytu. Orzecznictwo sądowe nie jest jeszcze ukształtowane i siłą rzeczy poniższe uwagi będą miały charakter tymczasowy.

Dostępne dane wskazuja, że w trzecim kwartale 2017 r. do sądów rejonowych wpłynęło 331, a do sądów okręgowych 614 nowych spraw o roszczenia związane $\mathrm{z}$ umowami kredytów powiązanych $\mathrm{z}$ walutą obcą. W czwartym kwartale 2017 r. nowych spraw było już 745 w sądach rejonowych i $1406 \mathrm{w}$ sądach okręgowych, a więc ponad dwa razy więcej ${ }^{50}$. Ponieważ we wcześniejszych okresach było składanych mniej pozwów (kredytobiorcy oczekiwali wówczas na rozwiązanie polityczne), to można szacować, że lawinowo rośnie w sądach liczba spraw związanych z umowami kredytowymi. Niemniej, można szacować, że łączna liczba spraw nie przekracza 10 tys. Oznacza to, że do sądu trafiło ok. $1 \%$ wszystkich umów. Nawet uwzględniając coraz większą liczbę rozpoczynanych postępowań grupowych (należy odnotować, że często reprezentantem takiej grupy jest miejski lub powiatowy rzecznik konsumentów, co stanowi przykład wsparcia konsumentów w dochodzeniu roszczeń na drodze sądowej), skupiających kilkuset czy nawet ponad tysiąc kredytobiorców, liczba kredytobiorców zaangażowanych w spór sądowy nie przekracza zapewne $5 \%$. Pokazuje to jednocześnie istotne ograniczenia związane z indywidualnym rozwiązywaniem problemu, który ma charakter masowy. Podstawowe powody, dla których tak mało spraw trafiło do sądu, to:

1. wysokie koszty postępowania sądowego, na które składa się zarówno opłata sądowa (od listopada 2005 r. wynosząca 5\% kwoty roszczenia,

${ }^{50}$ Dane za informacją Ministerstwa Sprawiedliwości o wpływie spraw oznaczonych symbolami 049c i 049cf. Oznaczenia te zostały wprowadzone do systemu statystyki sądowej dopiero od trzeciego kwartału 2017 r. 
ale nie więcej niż 1000 zł), koszty opinii biegłych, jak i wynagrodzenie pełnomocnika, które to koszty należy ponieść na początku trwania sprawy;

2. ryzyko związane z niepewnością dotyczącą wyniku postępowania i możliwością przegrania, co wiąże się z koniecznością zwrotu przeciwnikowi kosztów procesu, w tym kosztów adwokata lub radcy prawnego strony wygrywającej.

$W$ rezultacie koszty dochodzenia swoich praw przed sądem niewątpliwie dla wielu kredytobiorców, zwłaszcza tych o gorszej pozycji majątkowej, stanowią istotną przeszkodę. Sytuacji nie poprawia teoretyczna dostępność postępowań grupowych, gdyż te do tej pory znajdują się na bardzo wczesnym etapie procedowania. Samo postępowanie wstępne, które ma zdecydować o dopuszczeniu sprawy do merytorycznego rozpoznania, potrafi trwać latami. $W$ rezultacie żadne postępowanie grupowe w sprawach o klauzule waloryzacyjne nie weszło w fazę merytorycznego rozpoznania i trudno przewidzieć, ile takie postępowania ostatecznie potrwają.

Jednak najważniejszym elementem ryzyka jest niepewność co do wyniku. W tym zakresie możliwe są trzy rozwiązania problemu umów kredytów powiązanych z walutą obca, a mianowicie: (1) stwierdzenie nieważności umowy, (2) stwierdzenie bezskuteczności klauzul indeksacyjnych i wykonywanie umowy bez nich, z pozostawieniem zasad oprocentowania określonych w umowie oraz (3) wprowadzenie w miejsce bezskutecznych klauzul indeksacyjnych indeksacji według kursu rynkowego, np. kursu średniego NBP. Dodając do tego czwartą możliwość, tj. (4) oddalenie roszczeń kredytobiorców, otrzymujemy pełną paletę możliwości. Pomimo że w większości spraw istota problemu jest taka sama, sądy powszechne orzekają niejednolicie. Zapadły więc już orzeczenia stwierdzające nieważność umowy kredytu indeksowanego ${ }^{51}$ oraz denominowanego ${ }^{52}$; orzeczenia nakazujące wykonywanie umowy z pominięciem mechanizmu indeksacji ${ }^{53}$; wprowadzające kurs średni

${ }^{51}$ Zob. np. nieprawomocne wyroki Sądu Okręgowego (SO) w Warszawie: z 22 VIII 2016 r., sygn. III C 1073/14; z 17 V 2017 r., sygn. III C 299/15; z 4 X 2017 r., sygn. XXIV C 1094/14; z 24 XI 2017 r., sygn. XXV C 1059/16 - wszystkie wyroki niepublikowane.

${ }^{52}$ Nieprawomocny wyrok SO Warszawa-Praga z 2 XII 2016 r., sygn. III C 75/16; wyrok Sądu Apelacyjnego (SA) w Białymstoku z 17 I 2018 r., sygn. I ACa 674/17 - oba wyroki niepublikowane.

${ }^{53}$ Zob. np. nieprawomocny wyrok SO w Warszawie z 31 V 2017 r., sygn. II C 920/15, oraz wyrok SO w Warszawie z 16 X 2017 r., sygn. XXV C 1732/16; wyrok SO w Krakowie z 12 XII 2017 r., sygn. I C 316/15; prawomocny wyrok SO we Wrocławiu z 20 VII 2017 r., sygn. II Ca 2200/16, wyrok SO we Wrocławiu z 10VIII 2017 r., sygn. II Ca 2227/16; 
NBP zamiast kursu banku ${ }^{54}$; wreszcie w całości oddalające roszczenia kredytobiorcy ${ }^{55}$. Oczywiście, powyższy przegląd jest niepełny, wskazuje jednak na ogromne zróżnicowanie w wyrażanych opiniach prawnych na tle bardzo zbliżonego stanu faktycznego ${ }^{56}$. Jednocześnie należy zauważyć aktywność Prezesa UOKiK oraz Rzecznika Finansowego, którzy przedstawiają sądom - na wniosek kredytobiorcy - tzw. istotny pogląd w sprawie. Zgodnie z tymi poglądami klauzule indeksacyjne zawarte w umowach kredytu są nieuczciwe, a przez to bezskuteczne i nie wiążą kredytobiorców, sama zaś umowa powinna być wykonywana dalej bez ich stosowania. Istotny pogląd nie wiąże sądów, lecz może im zapewnić odpowiedni materiał dowodowy dla rozstrzygnięcia sprawy.

Rozbieżność orzecznictwa wynika również z braku jednoznacznego stanowiska Sądu Najwyższego. SN dotąd nie zajmował się wprost kwestią ważności i skuteczności klauzul indeksacyjnych zawartych w umowach. Wyroki, które do tej pory zapadły w SN, dotyczyły przeważnie innych problemów, w których kwestia klauzul indeksacyjnych nie była najważniejsza. Warto jednak przytoczyć kilka z orzeczeń SN w tym zakresie:

1. zgodnie z wyrokiem z 19 marca $2015 \mathrm{r} .{ }^{57}$ ustawa antyspreadowa od chwili jej wejścia w życie usunęła skutki abuzywności klauzul indeksacyjnych; kredytobiorcy nie przysługuje interes prawny w wytoczeniu powództwa o ustalenie bezskuteczności klauzul indeksacyjnych, a przepisy ustawy antyspreadowej nie stanowią przepisu dyspozytywnego w zakresie zasad indeksacji kredytu;

2. zgodnie z wyrokiem z 14 maja $2015 \mathrm{r}^{58}$ wyeliminowanie klauzuli abuzywnej nie może prowadzić do zmiany charakteru prawnego zobowią-

prawomocny wyrok SA w Szczecinie z 23 XI 2017 r., sygn. I ACa 516/17; prawomocny wyrok SA w Białymstoku z 14 XII 2017 r., sygn. I ACa 447/17 - wszystkie wyroki niepublikowane.

${ }^{54}$ Zob. prawomocny wyrok SO w Warszawie z 22 VI 2017 r., sygn. XXVII Ca 3477/16, niepublikowany.

${ }^{55}$ Zob. np. wyrok SO w Warszawie z 31 X 2017 r., sygn. I C 290/17, oraz wyrok SO w Warszawie z 23XI 2017 r., sygn. I C 185/17 - oba wyroki niepublikowane.

${ }^{56}$ Zróżnicowanie orzeczeń stało się przedmiotem wystąpienia Prezesa Sądu Okręgowego w Warszawie z dnia 16 I 2018 r. do Pierwszego Prezesa Sądu Najwyższego w sprawie istotnych rozbieżności w orzecznictwie sądowym w sprawach dotyczących kredytów powiązanych z kursem waluty obcej (http://bip.warszawa.so.gov.pl/artykul/113/3289/ wystapienie-prezesa-sadu-okregowego-w-warszawie-sso-joanny-bitner-do-pani-prof-malgorzaty-gersdorf-pierwszego-prezesa-sadu-najwyzszego, dostęp: 25 II 2018).

${ }^{57}$ Wyrok SN z 19 III 2015 r., sygn. IV CSK 362/14, niepublikowany.

${ }^{58}$ Wyrok SN z 14 V 2015 r., sygn. II CSK 768/14, Orzecznictwo Sądu Najwyższego Izba Cywilna 2015, nr 11, poz. 132. 
zania. Na gruncie przedmiotowej sprawy dotyczyło to kwestii, czy eliminacja klauzuli pozwalającej bankowi na arbitralną zmianę oprocentowania kredytu prowadzi do niemożności zmiany oprocentowania w całym okresie kredytowania. Sąd Najwyższy uznal, że eliminacja postanowienia umownego prowadzi do luki w umowie, która może być jednak uzupełniona poprzez odwołanie się do praktyki rynkowej, którą określi biegły;

3. zgodnie z wyrokiem z 22 stycznia $2016 \mathrm{r} .{ }^{59} \mathrm{klauzula}$ indeksacyjna nie dotyczy głównego świadczenia stron, co oznacza, że jest dopuszczalne badanie jej uczciwości, nawet jeżeli jest jednoznacznie sformułowana; jednocześnie SN uznał, że konstrukcja kredytu indeksowanego mieści się w ogólnej konstrukcji umowy kredytu i stanowi jeden z jej dopuszczalnych wariantów;

4. zgodnie $\mathrm{z}$ wyrokiem z 8 września $2016 \mathrm{r} .{ }^{60}$ dla obliczenia wysokości zadłużenia kredytobiorcy bank nie może stosować kursu dowolnie przez siebie wyznaczonego;

5. w wyroku z 14 lipca 2017 r. ${ }^{61}$ SN uznał, że dopuszczalne jest zaciągnięcie zobowiązania $\mathrm{w}$ walucie obcej $\mathrm{z}$ równoczesnym zastrzeżeniem, że wypłata i spłata kredytu będzie dokonywana w pieniądzu krajowym, a zastrzeżenie takie dotyczy wyłącznie sposobu wykonania zobowiązania, przez co nie powoduje zmiany waluty wierzytelności. Jednocześnie SN uznał, że luka w umowie może być uzupełniona, lecz tylko na korzyść konsumenta, jeżeli jej brak miałby powodować, że interesy konsumenta byłyby zagrożone, zgodnie z wykładnią Dyrektywy 93/13/EWG dokonaną przez TSUE w sprawie Kásler ${ }^{62}$. Wreszcie SN uznał, że stosowanie dwóch kursów do waloryzacji stanowi źródło dodatkowej korzyści dla banku, lecz w zamian za tę korzyść bank nie świadczy w istocie żadnej rzeczywistej usługi.

Jak widać, powyżej przywołane orzecznictwo SN nie dotyka jeszcze wprost kwestii wpływu klauzul indeksacyjnych na ważność całej umowy kredytu oraz skuteczność całego mechanizmu indeksacji. Najwięcej kontrowersji wywołał wyrok SN z 14 maja 2015 r. ${ }^{63}$ dotyczący skutków eliminacji nieuczciwej klauzuli z umowy. Wyrok ten wywołał

${ }^{59}$ Wyrok SN z 22 I 2016 r., sygn. I CSK 1049/14, Orzecznictwo Sądu Najwyższego Izba Cywilna 2016, nr 11, poz. 134.

${ }^{60}$ Wyrok SN z 8 IX 2016 r., sygn. II CSK 750/15, niepublikowany.

${ }^{61}$ Wyrok SN z 14 VII 2017 r., sygn. II CSK 803/16, niepublikowany.

${ }^{62}$ Wyrok TSUE z 30 IV 2014 r w sprawie Árpád Kásler i Hajnalka Káslerné Rábai przeciwko OTP Jelzálogbank Zrt. (C-26/13), ECLI:EU:C:2014:282.

${ }^{63}$ Wyrok SN z 14 V 2015 r., sygn. II CSK 768/14, niepublikowany. 
wiele krytycznych komentarzy w doktrynie ${ }^{64}$, a zaprezentowane w nim rozumowanie jest odrzucane przez te orzeczenia sądowe, które uznaja, że nieuczciwy mechanizm indeksacji nie może być zastąpiony przez inny, a akceptowany w tych orzeczeniach, które szukają w miejsce kursu bankowego innego, obiektywnego miernika wartości.

Przegląd orzeczeń pokazuje zróżnicowanie opinii sądów wynikające $\mathrm{z}$ rozproszenia spraw pomiędzy różne sądy. I chociaż z biegiem lat orzecznictwo sądowe niewątpliwie ulegnie ujednoliceniu, w chwili obecnej jest zbyt niejednolite, aby kredytobiorcy mogli być pewni swojej wygranej. Zważywszy zaś na fakt, że umowy kredytowe zawierane były przede wszystkim w latach 2005-2008, coraz większe znaczenie dla roszczeń kredytobiorców będzie miał upływ okresu przedawnienia. W rezultacie również i wykształcenie się jednolitej linii orzeczniczej sądów w tych sprawach - nawet kiedy będzie korzystne dla kredytobiorców - będzie w znacznym stopniu spóźnione.

\section{Podsumowanie}

Przeprowadzona analiza działań podejmowanych przez władze publiczne wykazała, że instytucje publiczne są bezradne wobec masowego wprowadzania na rynek produktu kredytu powiązanego z kursem waluty obcej, który przez specjalistów od początku był uważany za zbyt ryzykowny ${ }^{65}$. Nawet te banki, które były za zakazem udzielania tego typu kredytów, w pogoni za udziałem w rynku również oferowały ten produkt. Mieliśmy więc tutaj typowe zjawisko wyścigu do dna (race to the bottom), często opisywanego zjawiska, w którym konkurencja pomiędzy podmiotami prowadzi do osiągnięcia gorszego wyniku, niż

${ }^{64}$ Zob. np. J. Czabański, Glosa do wyroku Sądu Najwyższego z dnia 14.5.2015 r. (II CSK 768/14) [o klauzulach abuzywnych w tzw. kredytach walutowych], "Palestra” 2016, nr 1-2, s. 182; T. Czech, Odpowiedzialność banku za stosowanie abuzywnej klauzuli zmiennego oprocentowania - wyrok SN z 14 maja 2015 r. (II CSK 768/14), "Monitor Prawa Bankowego" 2016, nr 6, s. 34; A. Wiewiórowska-Domagalska, Bułgarski standard, „Dziennik Gazeta Prawna" 21 VIII 2015; K. Kurosz, Nieważność umowy kredytu na skutek wadliwego określenia warunków zmiany oprocentowania, "Przegląd Prawa Handlowego" 2017, nr 1, s. 17. Zob. też omówienie dyskusji w: M. Bławat, K. Pasko, O zakresie zachowania mocy wią̇acej umowy po eliminacji klauzul abuzywnych, "Transformacje Prawa Prywatnego" 2016, nr 3, s. 5.

${ }^{65}$ Zob. A. Adamczyk, J. Iwin, Analiza opłacalności kredytów indeksowanych i walutowych w warunkach gwattownych zmian cen na rynku walutowym, "Bank i Kredyt” 2002, nr 6, s. 53; B. Nowosielska, op. cit., s. 61. 
zapewniłaby współpraca. Taką współpracę mogłyby zapewnić wspólne reguły gry, a więc ustanowienie odpowiednich wymogów informacyjnych i prawnych: te jednak z początku były zbyt słabe - Rekomendacja S (I) i S (II), a kolejne były już spóźnione - ustawa antyspreadowa z 2011 r., Rekomendacja T z 2013 r. i ustawa o kredycie hipotecznym z 2017 r. Wobec skali problemu zawiodły również polityczne próby wprowadzenia rozwiązania systemowego, i to pomimo wielu negatywnych skutków społecznych dla kredytobiorców ${ }^{66}$. Nie powinno to dziwić, skoro generalnie ochrona konsumenta na rynku finansowym jest niewystarczająca. Jak stwierdziła Najwyższa Izba Kontroli w roku 2014, ponad $60 \%$ wzorców umów zawierało postanowienia niezgodne z przepisami lub naruszające interesy konsumentów, kary dla przedsiębiorców nie doprowadziły do zmniejszenia stopnia naruszeń praw konsumentów na rynku finansowym, użyteczność rejestru niedozwolonych klauzul umownych była ograniczona, sądy polubowne praktycznie nie działały, a droga sądowa była długotrwała i kosztowna ${ }^{67}$.

Z powyższego względu tylko nieliczna grupa kredytobiorców ok. 5\% - zdecydowała się na drogę sądową. Z punktu widzenia banku oznacza to, że nawet jeżeli przegra wszystkie te sprawy, to ostatecznie wygra, gdyż opłacało mu się stosować nieuczciwe postanowienia umowne wobec wszystkich. $W$ rezultacie nie został spełniony konstytucyjny postulat ochrony konsumentów, a konsumentom pozostała indywidualna droga ochrony prawnej.

Polskie orzecznictwo sądowe powinno podążyć za wykładnią Trybunału Sprawiedliwości Unii Europejskiej, który wielokrotnie podkreślał konieczność zagwarantowania odpowiedniego efektu prewencyjnego, jaki ma zapewnić eliminacja nieuczciwych postanowień bez zastępowania ich innymi ${ }^{68}$. TSUE podkreślił też wymóg jasnego informowania konsumentów o skutkach ekonomicznych i ryzyku związanym z umową kredytu powiązaną w walucie obcej ${ }^{69}$. Wykładnię TSUE przyjęły sądy

\footnotetext{
${ }^{66}$ A. Bartoszewicz, Społeczne skutki kryzysu kredytów hipotecznych odnoszacych się do walut obcych, "Zeszyty Naukowe Polskiego Towarzystwa Ekonomicznego w Zielonej Górze" 2017, nr 6, s. 5.

${ }^{67}$ Zob. Funkcjonowanie systemu ochrony praw klientów podmiotów rynku finansowego. Informacja o wynikach kontroli, Najwyższa Izba Kontroli, 2014, https://www.nik.gov.pl/ aktualnosci/nik-o-ochronie-klientow-rynku-finansowego.html (dostęp: 16 III 2018).

${ }^{68}$ Zob. np. niedawny wyrok TSUE z 21 XII 2016 r. w połączonych sprawach C-154/15, C-307/15 i C-308/15, ECLI:EU:C:2016:980.

${ }^{69}$ Wyrok TSUE z 20 IX 2017 r. Ruxandra Paula Andriciuc i in. przeciwko Banca Românească SA.
} 
w wielu państwach UE w analogicznych sprawach ${ }^{70}$. Również i polskie sądy powinny realizować konstytucyjny wymóg ochrony konsumenta i nakazać stosowanie umów bez nieuczciwych postanowień umownych $\mathrm{i}$ bez ich zastępowania postanowieniami $\mathrm{w}$ interesie przedsiębiorcy. Tylko poprzez eliminację z umów elementu ryzyka, o którym konsumenci nie zostali właściwie poinformowani, banki zostaną pozbawione nieuczciwych korzyści oraz zostanie wywarty odpowiedni efekt odstraszający chroniący konsumentów w przyszłości.

\section{THE EFFICACY OF PUBLIC AND JUDICIAL REVIEW OF THE FAIRNESS OF MORTGAGE LOANS INDEXED TO FOREIGN CURRENCIES}

\section{S u m mary}

The article discusses problems created by the introduction of foreign currencies mortgage loans (especially indexed to the Swiss Franc) into the mass consumer market in Poland (mainly in years 2005-2008). Approximately 900 thousands of Polish consumers have their mortgage loans indexed to foreign currencies. This kind of loan became very popular due to lower interest rates. However, indexation of mortgage loan to foreign currency has also exposed borrowers to foreign exchange risk of which consumers were insufficiently informed. This risk has materialised to some extent with sharp increases in CHF exchange rate in 2009 and 2015. The article reports the unsuccessful attempts of self-regulation of the banking sector as well as delayed actions undertaken by regulatory bodies, namely the Banking Supervision Authority, and subsequently, the Polish Financial Supervision Authority, which tried to limit the scope of such risky loans on the consumer market. As political attempts to solve the problem have also been unfruitful, the individual litigations in civil courts have become of particular significance.

The courts have not reached a common approach to individual claims yet. In some judgments such loans are declared null and void, in others orders are issued to perform the loans but disregarding the unfair terms of indexation. There are also judgments that declare such contracts perfectly legal. The author discusses the present case-law and presents a preferred direction of action which in his opinion may provide full protection of consumers against unfair contract terms which would be at the same time in line with the requirements of the Court of Justice of the European Union.

Keywords: foreign currencies mortgage loans - unfair terms - Polish Financial Supervision Authority

${ }^{70}$ Na przykład wyrok Sądu Najwyższego w Hiszpanii z 15 XI 2017 r., sygn. 608/2017, wyrok Sądu Apelacyjnego w Ljubljanie (Słowenia) z 19 I 2018 r. czy wyroki sądów w Atenach (Grecja) z 24 V 2016 oraz 25 IX 2017 r. 